\title{
STUDIES ON TOMAYMYCIN. I \\ THE STRUCTURE DETERMINATION OF TOMAYMYCIN ON THE BASIS OF NMR SPECTRA
}

\author{
ZENZABUro TOZUKA and TAKaO TAKAYA* \\ Research Laboratories, Fujisawa Pharmaceutical Co., Ltd. \\ Kashima, Yodogawaku, Osaka, Japan \\ (Received for publication September 13, 1982)
}

\begin{abstract}
The structure of an antitumor antibiotic, tomaymycin, was determined as $(11 R, 11 a S)$ (E)-2-ethylidene-2,3,5,10,11,11a-hexahydro-8-hydroxy-7,11-dimethoxy-5-oxo-1 H-pyrrolo(2,1-c)$(1,4)$ benzodiazepine on the basis of ${ }^{1} \mathrm{H}$ and ${ }^{13} \mathrm{C}$ NMR spectra.
\end{abstract}

Tomaymycin ${ }^{1)}$ is one of the pyrrolo $(1,4)$ benzodiazepine antibiotics, such as anthramycin ${ }^{2)}$, neothramycin ${ }^{3)}$, and sibiromycin ${ }^{4}$. It fascinated us as a synthetic target because of the strong antitumor activity in addition to its interesting structure. The configuration at the asymmetric C-11 and the geometrical isomerism of the 2-ethylidene group in tomaymycin were not clear when we started the total synthesis of tomaymycin ${ }^{5)}$, although the plane structural formula had been determined by the chemical degradation method $^{\theta)}$. In this paper, we wish to describe the structure determination of tomaymycin on the basis of NMR spectra. The $100 \mathrm{MHz}^{1} \mathrm{H}$ NMR spectra of both $E$ - (1E) and $Z$-tomaymycin (1Z) in DMSO- $d_{8}$ were the very similar as shown in Table 3. It was impossible to distinguish between the $E$ - and $Z$-isomer by using the technique of NOE between the ethylidene group and the adjacent methylene groups. However, ${ }^{13} \mathrm{C}$ NMR spectrometry is potentially an extremely attractive tool for structural elucidation of the geometrical isomerism of the ethylidene moiety of tomaymycin. A high field shift arising from the steric shielding effect in the ${ }^{18} \mathrm{C}$ NMR spectra was found for an extensive series of methylbenzenes by WOOLFENDEN and GRANT ${ }^{7)}$ and also for ethylidenecyclopentane by LIPPMAA et al. ${ }^{8)}$ In order to clarify the configuration of the ethylidene moiety, two geometrical isomers of 4-ethylidene-L-proline diphenylmethyl ester were prepared from L-hydroxyproline as model compounds. The structure determination of tomaymycin on the basis of NMR spectra agreed with the crystal structure determined by the X-

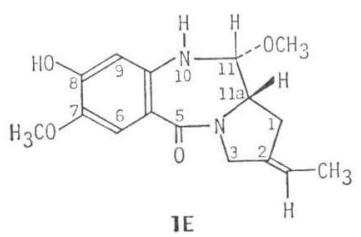

$\boldsymbol{E}$-Tomaymycin

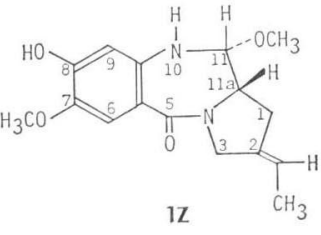

$z$-Tomaymyc in ray analysis of tomaymycin which was recently reported by ARORA. ${ }^{9)}$

Syntheses of $(E)$ - and ( $Z$ )-4-Ethylidene-L-proline Diphenylmethyl Esters

4-Ethylidene-L-proline diphenylmethyl esters ( $7 \mathbf{E}$ and $7 \mathbf{Z}$ ) were prepared according to the modified procedure reported by Bethell et al. ${ }^{10)}$ (Scheme 1). $\quad N$-t-Butoxycarbonyl-L-hydroxyproline diphenylmethyl ester (4) was prepared by the reaction of L-hydroxyproline (2) with 2-phenyl-2-t-butoxycarbonyloxyiminoacetonitrile (Boc-ON), followed by esterification using diphenyldiazomethane, in an excellent yield. The improved MofFATT oxidation of $\mathbf{4}$ with DMSO-trifluoroacetic acid (TFA)-pyridine-dicyclo- 
Scheme 1.

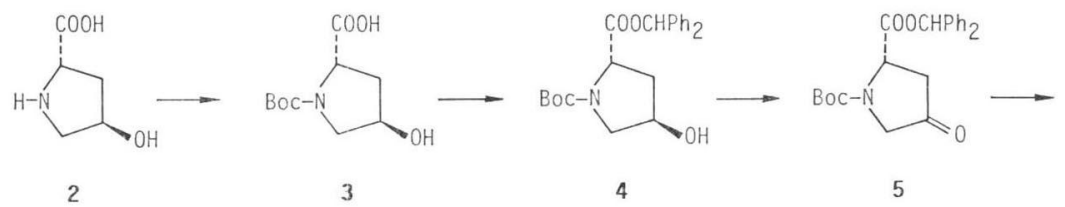<smiles>CC(=O)N1CC(=CC2CCCCC2)CC1C(=O)OCc1ccccc1</smiles>

$6 \mathrm{E}$<smiles>CC(=O)C1CC(C(=O)O)CN1C(=O)OC(C)(C)C</smiles>

67

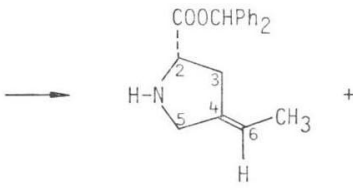

TE

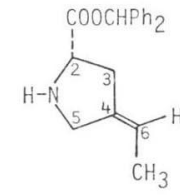

$7 Z$

hexylcarbodiimide $(\mathrm{DCC})^{11)}$ or with dimethyl sulfoxide (DMSO)-trifluoroacetic anhydride (TFAA)triethylamine (TEA) ${ }^{12)}$ gave the corresponding 4-oxo-L-proline derivative (5) in a good yield. The WITTIG reaction of $\mathbf{5}$ with the ylide obtained from the reaction of ethyltriphenylphosphonium bromide and sodium amide in liquid ammonia gave a mixture of $(E)$ - and $(Z)$-ethylidene derivatives ( $6 \mathrm{E}$ and $6 Z$ ) in $66 \%$ yield. They were separated by repeated column chromatography on silica gel with benzene. Removal of the $t$-butoxycarbonyl group of 6 with hydrogen chloride in methanol gave 7 in more than $90 \%$ yield.

The ${ }^{13} \mathrm{C}$ NMR Spectra of 4-Ethylidene-L-proline Diphenylmethyl Esters

Table 1 shows the ${ }^{13} \mathrm{C}$ NMR spectra of $(E)$ - and $(Z)$-ethylidene-L-proline diphenylmethyl ester (7E and $7 Z$ ) in which signals were assigned by analysis of both off-resonance ${ }^{1} \mathrm{H}$-decoupled and fully ${ }^{1} \mathrm{H}$ coupled ${ }^{13} \mathrm{C}$ NMR spectra. The chemical shift (32.6 ppm) of the methylene group at C-3 of the $E$-isomer (7E), which is influenced by the steric shielding effect of the methyl group in the ethylidene moiety, is $4.0 \mathrm{ppm}$ higher field than that of the $Z$-isomer (7Z) (36.6 ppm). On the other hand, the chemical shift $(47.8 \mathrm{ppm})$ of the methylene group at $\mathrm{C}-5$ of the $Z$-isomer is $3.3 \mathrm{ppm}$ higher field than that of the $E$-isomer (51.1 ppm) due to the same steric shielding effect. Thus the geometrical isomerism of the ethylidene moiety of 4ethylidene-L-proline diphenylmethyl ester was determined on the basis of the steric shielding effect in the ${ }^{19} \mathrm{C}$ NMR spectra.

Table 1. ${ }^{13} \mathrm{C}$ NMR spectra of 4-ethylidene-L-proline diphenylmethyl esters.

\begin{tabular}{l|ccc}
\hline & $\mathbf{7 E}$ & $\mathbf{7 Z}$ & Difference \\
\hline 2 & $60.1(\mathrm{~d})$ & $60.1(\mathrm{~d})$ & 0 \\
3 & $32.6(\mathrm{t})$ & $36.6(\mathrm{t})$ & 4.0 \\
4 & - & - & - \\
5 & $51.1(\mathrm{t})$ & $47.8(\mathrm{t})$ & -3.3 \\
6 & $115.2(\mathrm{~d})$ & $115.7(\mathrm{~d})$ & 0.5 \\
$6-\mathrm{CH}_{3}$ & $14.7(\mathrm{q})$ & $14.7(\mathrm{q})$ & 0 \\
$\mathrm{CO}_{2}$ & $173.5(\mathrm{~s})$ & $173.5(\mathrm{~s})$ & 0 \\
\hline
\end{tabular}

ppm (multiplicity on off-resonance)

Run in benzene with TMS as internal standard.

\section{The ${ }^{19} \mathrm{C}$ NMR Spectra of Tomaymycin}

The same steric shielding effect was observed in the ${ }^{13} \mathrm{C}$ NMR spectra of both $E$ - and $Z$-tomaymycin $(\mathbf{E}$ and $\mathbf{1 Z})$ as shown in Table 2. The chemical shift (32.3 ppm) of the methylene group at $\mathrm{C}-1$ of $\mathbf{1 E}$, which is influenced by the steric shielding effect of the methyl group, is $1.4 \mathrm{ppm}$ higher field than that of $\mathbf{1 Z}(33.7 \mathrm{ppm})$. On the other hand, the chemical shift $(51.2 \mathrm{ppm})$ of the methylene group at $\mathrm{C}-3 \mathrm{of} \mathbf{1 Z}$ is $2.6 \mathrm{ppm}$ higher field than that of $\mathbf{1 E}(53.8 \mathrm{ppm})$. Thus the geometrical isomerism of the ethylidene 
Table 2. ${ }^{13} \mathrm{C}$ NMR spectra of $E$ - (1E) and $Z$-tomaymycin (1Z).

\begin{tabular}{l|rr||r|rc}
\hline & $\mathbf{1 E}(\mathrm{ppm})$ & $\mathbf{1 Z}(\mathrm{ppm})$ & & $\mathbf{1 E}(\mathrm{ppm})$ & $\mathbf{1 Z}(\mathrm{ppm})$ \\
\hline 1 & 32.3 & 33.7 & 9 & $115.0^{*}$ & $114.8^{*}$ \\
2 & 108.9 & 108.4 & $9 \mathrm{a}$ & $140.0^{*}$ & $140.7^{*}$ \\
3 & 53.8 & 51.2 & 11 & 88.6 & 88.2 \\
5 & 165.2 & 165.1 & $11 \mathrm{a}$ & 53.4 & 53.8 \\
$5 \mathrm{a}$ & $114.7^{*}$ & $114.6^{*}$ & 12 & 103.7 & 104.1 \\
6 & $134.9^{*}$ & $135.0^{*}$ & $12-\mathrm{CH}_{3}$ & 14.1 & 14.1 \\
7 & $139.4^{*}$ & $138.9^{*}$ & $7-\mathrm{OCH}_{3}$ & 58.1 & 59.0 \\
8 & $150.5^{*}$ & $150.4^{*}$ & $11-\mathrm{OCH}_{3}$ & 55.9 & 55.9 \\
\hline
\end{tabular}

Run in DMSO- $d_{0}$ with TMS as internal standard.

* Assignments within any vertical column may be reversed.

moiety of tomaymycin was determined on the basis of ${ }^{13} \mathrm{C}$ NMR spectra.

The ${ }^{1} \mathrm{H}$ NMR Spectra of Tomaymycin

The KARPLUS rule ${ }^{13)}$, the relation between vicinal coupling in the ${ }^{1} \mathrm{H}$ NMR spectrum and the dihedral angle, was applied to estimate the configuration of $\mathrm{C}-11$ of tomaymycin. Table 3 shows the ${ }^{1} \mathrm{H}$ NMR spectra of $E$ - and $Z$-tomaymycin (1E and 1Z) in which $\mathrm{H}-10(7.10 \mathrm{ppm}, \mathrm{d}, J=6 \mathrm{~Hz})$ and $\mathrm{H}-11$ ( $4.50 \mathrm{ppm}, \mathrm{d}, J=6 \mathrm{~Hz}$ ) are coupled with each other. On exchange with $\mathrm{D}_{2} \mathrm{O}$, the former doublet peak disappeared, and the later doublet peak was changed to a singlet peak. The coupling constant $\left(J_{10,11}=\right.$ $6 \mathrm{~Hz}$ ) indicates that the dihedral angle of $\mathrm{H}_{10}-\mathrm{N}_{10}-\mathrm{C}_{11}-\mathrm{H}_{11}$ is $0 \sim 35^{\circ}$ or $145 \sim 180^{\circ}$. The H-11a (3.90 ppm, dd, $J=9 \mathrm{~Hz}, 5 \mathrm{~Hz}$ ) was not affected by exchange with $\mathrm{D}_{2} \mathrm{O}$ and coupled only with the two protons at C-1. As there is no coupling between $\mathrm{H}-11$ and $\mathrm{H}-11 \mathrm{a}$, the dihedral angle of $\mathrm{H}_{11}-\mathrm{C}_{11}-\mathrm{C}_{11 \mathrm{a}}-\mathrm{H}_{11 \mathrm{a}}$ is

Table 3. ${ }^{1} \mathrm{H}$ NMR spectra of $E$ - (1E) and $Z$-tomaymycin (1Z).

\begin{tabular}{c|ll}
\hline & \multicolumn{1}{|c}{$\mathbf{1 E}$} & \multicolumn{1}{c}{$\mathbf{1 Z}$} \\
\hline $1-\mathrm{Ha}$ & $2.96(1 \mathrm{H}, \mathrm{dd}, 18,9)$ & $2.96(1 \mathrm{H}, \mathrm{dd}, 18,9)$ \\
$1-\mathrm{Hb}$ & $2.55(1 \mathrm{H}, \mathrm{d}, 18)$ & $2.56(1 \mathrm{H}, \mathrm{d}, 18)$ \\
$3-\mathrm{H}$ & $4.12(2 \mathrm{H}, \mathrm{s})$ & $4.12(2 \mathrm{H}, \mathrm{s})$ \\
$6-\mathrm{H}$ & $7.20(1 \mathrm{H}, \mathrm{s})$ & $7.20(1 \mathrm{H}, \mathrm{s})$ \\
$9-\mathrm{H}$ & $6.23(1 \mathrm{H}, \mathrm{s})$ & $6.23(1 \mathrm{H}, \mathrm{s})$ \\
$11-\mathrm{H}$ & $4.49(1 \mathrm{H}, \mathrm{d}, 6)$ & $4.50(1 \mathrm{H}, \mathrm{d}, 6)$ \\
$11 \mathrm{a}-\mathrm{H}$ & $3.88(1 \mathrm{H}, \mathrm{dd}, 9,5)$ & $3.90(1 \mathrm{H}, \mathrm{dd}, 9,5)$ \\
$12-\mathrm{H}$ & $5.2 \sim 5.6(1 \mathrm{H}, \mathrm{m})$ & $5.2 \sim 5.6(1 \mathrm{H}, \mathrm{m})$ \\
$12-\mathrm{CH}_{3}$ & $1.59(3 \mathrm{H}, \mathrm{s})$ & $1.61(3 \mathrm{H}, \mathrm{s})$ \\
$7-\mathrm{OCH}$ & $3.66(3 \mathrm{H}, \mathrm{s})$ & $3.68(3 \mathrm{H}, \mathrm{s})$ \\
$11-\mathrm{OCH}$ & $3.20(3 \mathrm{H}, \mathrm{s})$ & $3.21(3 \mathrm{H}, \mathrm{s})$ \\
$10-\mathrm{NH}$ & $7.08(1 \mathrm{H}, \mathrm{d}, 6)$ & $7.10(1 \mathrm{H}, \mathrm{d}, 6)$ \\
$8-\mathrm{OH}$ & $9.32(1 \mathrm{H}, \mathrm{s})$ & $9.35(1 \mathrm{H}, \mathrm{s})$ \\
\hline
\end{tabular}

ppm (integration, multiplicity, coupling $\mathrm{Hz}$ )

Run in DMSO- $d_{8}$ at $100 \mathrm{MHz}$ with TMS as internal standard. approximately $90^{\circ}$. In order to visualize the above results in the ${ }^{1} \mathrm{H}$ NMR spectra of $1 \mathrm{E}$ and $1 Z$, Dreiding models were constructed. The configuration of the asymmetric C-11 of tomaymycin was estimated to have the $R$ configuration from the Dreiding models.

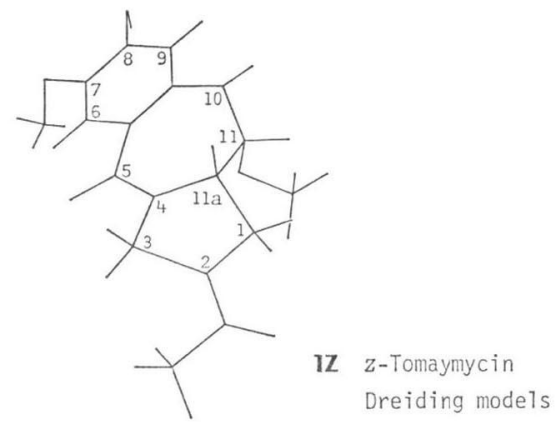

\section{Experimental}

${ }^{1} \mathrm{H}$ NMR and ${ }^{13} \mathrm{C}$ NMR spectra were measured at $100 \mathrm{MHz}$ on a JEOL-MH 100 NMR spectrometer and at $60 \mathrm{MHz}$ on a JNM-PMX 60 NMR spectrometer using TMS as an internal standard. 
The ${ }^{1} \mathrm{H}$ NMR spectra of compounds $4,5,6 \mathrm{E}$, and $6 \mathrm{Z}$ at room temperature predict the rotational isomerism due to restricted rotation of the two bulky groups ( $t$-butoxycarbonyl group and diphenylmethoxycarbonyl group, of which peaks were split). IR spectra were measured on a Hitachi 260-10 spectrophotometer. Melting points were taken with an Arthur H. Thomas melting point apparatus and were uncorrected. Elemental analyses were measured on a Yanaco CHN coder MT-2.

$N$ - $t$-Butoxycarbonyl-L-hydroxyproline (3)

A mixture of $2(131 \mathrm{~g})$, TEA (303 g), and Boc-ON (270 g) in 50\% (v/v) aqueous dioxane (2 liters) was stirred at room temperature for 5 hours. The resulting solution was washed with $\mathrm{CH}_{2} \mathrm{Cl}_{2}(3 \times$ $300 \mathrm{ml}$ ) and the separated aqueous layer was adjusted to $\mathrm{pH} 3.0$ with conc. $\mathrm{HCl}$. The acidified solution was extracted with EtOAc $(5 \times 500 \mathrm{ml})$. The extracts were washed with brine, dried over $\mathrm{MgSO}_{4}$, filtered, and evaporated in vacuo to give $3(177 \mathrm{~g}, 76.7 \%)$. An analytical sample was recrystallized from EtOAc, mp $126 \sim 127^{\circ} \mathrm{C}$ : IR (Nujol) $3350,1730,1655 \mathrm{~cm}^{-1}$ : NMR (DMSO- $d_{\theta}$ ) $\delta 1.4(9 \mathrm{H}, \mathrm{s}), 1.8 \sim 2.4$ $(2 \mathrm{H}, \mathrm{m}), 3.07 \sim 3.7(2 \mathrm{H}, \mathrm{m}), 4.0 \sim 4.53(2 \mathrm{H}, \mathrm{m})$.

Anal. Calcd. for $\mathrm{C}_{10} \mathrm{H}_{17} \mathrm{NO}_{5}$ : C 51.97, $\mathrm{H} 7.41, \mathrm{~N} 6.06$.

Found:

C 52.01, H 7.57, N 6.20.

$N$ - $t$-Butoxycarbonyl-L-hydroxyproline Diphenylmethyl Ester (4)

To a solution of benzophenone hydrazone $(196 \mathrm{~g})$ in EtOAc (one liter) was added nickel oxide $(483 \mathrm{~g})$ at $0 \sim 10^{\circ} \mathrm{C}$. The mixture was stirred for one hour and filtered. The filtrate was added to a solution of $3(177 \mathrm{~g})$ in EtOAc (one liter). The solution was stirred at room temperature overnight and the excess of diphenyldiazomethane was decomposed with AcOH. The solution was washed with $5 \%$ aqueous $\mathrm{NaHCO}_{3}$ and water. The organic layer was dried over $\mathrm{MgSO}_{4}$, filtered, and evaporated in vacuo. The residue was dissolved in a little EtOAc and the solution was added to $n$-hexane with stirring. The resulting powder was filtered and air-dried to give $4(256 \mathrm{~g}, 84.2 \%), \mathrm{mp} 103 \sim 104^{\circ} \mathrm{C}$ : IR(Nujol) 3500 , $1720,1690 \mathrm{~cm}^{-1}$ : NMR (DMSO- $\left.d_{6}\right) \delta 1.17,1.38(9 \mathrm{H}$, two s), $1.77 \sim 2.33(2 \mathrm{H}, \mathrm{m}), 3.13 \sim 3.67(2 \mathrm{H}, \mathrm{m})$, $5.10(1 \mathrm{H}, \mathrm{d}, J=4 \mathrm{~Hz}), 6.83,6.90(1 \mathrm{H}$, two s), $7.38(10 \mathrm{H}, \mathrm{s})$.

Anal. Calcd. for $\mathrm{C}_{23} \mathrm{H}_{27} \mathrm{NO}_{5}$ : C 69.50, $\mathrm{H} 6.85, \mathrm{~N} 3.52$.

Found:

C 69.55, H 6.89, N 3.53 .

$N$-t-Butoxycarbonyl-4-oxo-L-proline Diphenylmethyl Ester (5)

A solution of $4(236 \mathrm{~g})$ in DMSO $(500 \mathrm{ml})$ was added to a solution of TFA $(24 \mathrm{ml})$ in pyridine $(48 \mathrm{ml})$ at $3^{\circ} \mathrm{C}$. To the solution was added DCC $(372 \mathrm{~g})$ at the same temperature and the mixture was stirred at room temperature overnight. After the reaction mixture was diluted with $\mathrm{Et}_{2} \mathrm{O}$ (3 liters), a solution of oxalic acid $(162 \mathrm{~g})$ in $\mathrm{MeOH}(500 \mathrm{ml})$ was added to the mixture. After the evolution of gas had ceased, $\mathrm{H}_{2} \mathrm{O}(500 \mathrm{ml})$ was added to the mixture and the insoluble substances were filtered off. The filtrate was washed with $5 \%$ aqueous $\mathrm{NaHCO}_{3}$ and water, dried over $\mathrm{MgSO}_{4}$, filtered, and evaporated to dryness in vacuo. The residue was triturated with $50 \%(\mathrm{v} / \mathrm{v}) n$-hexane $-\mathrm{Et}_{2} \mathrm{O}$ to give $\mathbf{5}(197 \mathrm{~g}, 83.9 \%), \mathrm{mp} 97 \sim$ $98^{\circ} \mathrm{C}$ : IR (Nujol) $1760,1740,1700 \mathrm{~cm}^{-1}$ : NMR (DMSO- $d_{6}$ ) $\delta 1.27,1.4$ (9H, two s), $2.45(1 \mathrm{H}, \mathrm{dd}, J=$ $18 \mathrm{~Hz}, 3 \mathrm{~Hz}), 3.27(1 \mathrm{H}, \mathrm{dd}, J=18 \mathrm{~Hz}, 10 \mathrm{~Hz}), 3.65(1 \mathrm{H}, \mathrm{d}, J=18 \mathrm{~Hz}), 3.98(1 \mathrm{H}, \mathrm{d}, J=18 \mathrm{~Hz}), 4.82(1 \mathrm{H}$, dd, $J=10 \mathrm{~Hz}, 3 \mathrm{~Hz}), 6.86(1 \mathrm{H}, \mathrm{s}), 7.35(10 \mathrm{H}, \mathrm{s})$.

Anal. Calcd. for $\mathrm{C}_{23} \mathrm{H}_{25} \mathrm{NO}_{5}$ : C 69.86, $\mathrm{H} 6.37, \mathrm{~N} 3.53$.

Found:

C 69.60, H 6.47, N 3.72 .

$N$-t-Butoxycarbonyl-4-ethylidene-L-proline Diphenylmethyl Ester (6)

All operations were carried out in an atomosphere of oxygen-free nitrogen. To freshly distilled liquid ammonia $(400 \mathrm{ml})$ was added sodium $(3.8 \mathrm{~g})$ and a trace of ferric chloride. When the blue color had disappeared, ethyltriphenylphosphonium bromide $(61.4 \mathrm{~g})$ was added with stirring. After stirring for 2 hours, ammonia was removed and the reaction mixture was heated at $50^{\circ} \mathrm{C}$ for 20 minutes. To the mixture were added dry tetrahydrofuran (THF, $400 \mathrm{ml})$ and dry ether $(100 \mathrm{ml})$. To the suspension was added a solution of $5(10 \mathrm{~g})$ in THF $(300 \mathrm{ml})$ at room temperature with stirring. The resulting mixture was refluxed for 24 hours, cooled with water bath, and filtered. The filtrate was evaporated in vacuo. The residue was chromatographed on silica gel with benzene to give the mixture of $6 \mathrm{E}$ and $6 \mathrm{Z}(6.8 \mathrm{~g}$, $66 \%$ ) which were separated by repeated chromatography on silica gel with benzene. The earlier fraction gave pure $6 \mathrm{Z}$ as colorless oil $\left(0.95 \mathrm{~g}, 9.2 \%\right.$ ), IR (film) $1740,1700 \mathrm{~cm}^{-1}$ : NMR $\left(\mathrm{CDCl}_{3}\right) \delta 1.27,1.47(9 \mathrm{H}$, 
two s), $1.58(3 \mathrm{H}, \mathrm{d}, J=8 \mathrm{~Hz}), 2.53(2 \mathrm{H} \mathrm{d}, J=18 \mathrm{~Hz}), 4.10(2 \mathrm{H}, \mathrm{s}), 4.33 \sim 4.73(1 \mathrm{H}, \mathrm{m}), 5.1 \sim 5.57(1 \mathrm{H}, \mathrm{m})$, $6.92(1 \mathrm{H}, \mathrm{s}), 7.3(10 \mathrm{H}, \mathrm{s})$.

Anal. Calcd. for $\mathrm{C}_{25} \mathrm{H}_{28} \mathrm{NO}_{4}$ : C 73.68, H 7.17, $\mathrm{N} 3.44$.

Found:

C 73.37, H 7.12, N 3.45 .

The latter fraction gave approximately pure $6 \mathrm{E}$ as pale yellow oil $(1.2 \mathrm{~g}, 11.6 \%$ ), IR (film) 1740 , $1700 \mathrm{~cm}^{-1}$ : NMR (DMSO- $\left.d_{6}\right) \delta 1.22,1.42(9 \mathrm{H}$, two s), $1.55(3 \mathrm{H}, \mathrm{d}, J=8 \mathrm{~Hz}), 2.2 \sim 2.7(2 \mathrm{H}, \mathrm{m}), 4.0(2 \mathrm{H}$, m), $4.5(1 \mathrm{H}, \mathrm{dd}, J=10 \mathrm{~Hz}, 3 \mathrm{~Hz}), 5.1 \sim 5.5(1 \mathrm{H}, \mathrm{m}), 6.88(1 \mathrm{H}, \mathrm{s}), 7.37(10 \mathrm{H}, \mathrm{s})$.

(Z)-4-Ethylidene-L-proline Diphenylmethyl Ester (7Z)

To an ice-cooled solution of $6 \mathrm{Z}(3.83 \mathrm{~g})$ in $\mathrm{MeOH}(20 \mathrm{ml})$ was added a solution of $\mathrm{MeOH}$ saturated with $\mathrm{HCl}$ gas. The solution was stirred at room temperature for one hour and neutralized with TEA. The resulting precipitate was filtered and washed with ether. The filtrate and the washing were combined and evaporated in vacuo. The residue was dissolved in EtOAc, washed with water, dried over $\mathrm{MgSO}_{4}$, and evaporated in vacuo. The residue was chromatographed on silica gel. The eluate with EtOAc was evaporated to give $7 Z\left(2.65 \mathrm{~g}, 91.7 \%\right.$ ), IR (film) $3350,1730 \mathrm{~cm}^{-1}$ : NMR (DMSO- $\left.d_{8}\right) \delta 1.56$ (3H, m), $2.20(1 \mathrm{H}, \mathrm{dd}, J=18 \mathrm{~Hz}, 6 \mathrm{~Hz}), 3.10(1 \mathrm{H}, \mathrm{dd}, J=18 \mathrm{~Hz}, 12 \mathrm{~Hz}), 3.48$ (2H, br. s), 3.95 (1H, dd, $J=12 \mathrm{~Hz}, 6 \mathrm{~Hz}), 5.16 \sim 5.52(1 \mathrm{H}, \mathrm{m}), 6.84(1 \mathrm{H}, \mathrm{s}), 7.40(10 \mathrm{H}, \mathrm{s})$.

(E)-4-Ethylidene-L-proline Diphenylmethyl Ester (7E)

$7 \mathrm{E}$ was similarly prepared from $6 \mathrm{E}(1.1 \mathrm{~g})$ in $90.4 \%$ yield, IR (film) $3340,1740 \mathrm{~cm}^{-1}$. NMR $\left(\mathrm{DMSO}-d_{6}\right) \delta 1.56(3 \mathrm{H}, \mathrm{m}), 2.20(1 \mathrm{H}, \mathrm{dd}, J=18 \mathrm{~Hz}, 6 \mathrm{~Hz}), 3.10(1 \mathrm{H}, \mathrm{dd}, J=18 \mathrm{~Hz}, 12 \mathrm{~Hz}), 3.48$ (2H, br. s), $3.95(1 \mathrm{H}, \mathrm{dd}, J=12 \mathrm{~Hz}, 6 \mathrm{~Hz}), 5.16 \sim 5.5(1 \mathrm{H}, \mathrm{m}), 6.84(1 \mathrm{H}, \mathrm{s}), 7.40(10 \mathrm{H}, \mathrm{s})$.

\section{Acknowledgment}

The authors are grateful to M. SHIGI for his helpful advice and kind assistance with NMR spectrometry.

\section{References}

1) Arima, K.; M. Kohsaka, G. Tamura, H. Imanaka \& H. Sakai: Studies on tomaymycin, a new antibiotic. I. Isolation and properties of tomaymycin. J. Antibiotics 25: 437 444, 1972

2) Leimgruber, W.; V. Stefanovic, F. Schenker, A. Karr \& J. Berger: Isolation and characterization of anthramycin, a new antitumor antibiotic. J. Amer. Chem. Soc. 87: 5791 5793, 1965

3) Takeuchi, T.; M. Mryamoto, M. Ishizuka, H. Naganawa, S. Kondo, M. Hamada \& H. Umezawa: Neothramycins A and B, new antitumor antibiotics. J. Antibiotics 29: 93 96, 1976

4) Brazhnikova, M. G.; N. V. Konstantinova \& A. S. Mesentsev: Sibiromycin: Isolation and characterization. J. Antibiotics 25: 668 673, 1972

5) Tozuka, Z.; H. Takasugi \& T. Takaya: Studies on tomaymycin. II. Total syntheses of antitumor antibiotics, $E$ - and $Z$-tomaymycin. J. Antibiotics 36(3): in press.

6) Kariyone, K.; H. Yazawa \& M. KohsaKa: The structure of tomaymycin and oxotomaymycin. Chem. Pharm. Bull. 19: 2289 2293, 1971

7) Woolfenden, W. R. \& D. M. Grant: Carbon-13 magnetic resonance. V. Conformational dependence of the chemical shifts in the methylbenzenes. J. Amer. Chem. Soc. 88: 1496 1502, 1966

8) Lippmaa, E.; T. Pehk, J. Paasivirta, N. Belikova \& A. Plate: Carbon-13 chemical shifts of bicyclic compounds. Org. Magn. Resonance 2: 581 604, 1970

9) Arora, S. K.: Structure of tomaymycin, a DNA binding antitumor antibiotic. J. Antibiotics 34: 462 464, 1981

10) Bethell, M. \& G. W. Kenner: Peptides. XV. 4-Methyleneproline and 4-hydroxymethylproline. J. Chem. Soc. 1965: 3850 3854, 1965

11) Plitzner, K. E. \& J. G. Moffatt: Sulfoxide-carbodiimide reactions. II. Scope of the oxidation reaction. J. Amer. Chem. Soc. 87: 5670 5678, 1965

12) Omura, K.; A. K. Sharma \& D. Swern: Dimethyl sulfoxide-trifluoroacetic anhydride, a new reagent for oxidation of alcohols to carbonyls. J. Org. Chem. 41: 957 962, 1976

13) JACKMAN, L. M. \& S. SternhelL: "Application of Nuclear Magnetic Resonance Spectroscopy in Organic Chemistry", 2nd ed., pp. 280 304, Pergamon Press, Oxford, London, Edinburgh, New York, Toront, Sydney, Paris, Braunschweig, 1969 